\title{
Gastro-intestinal nematodes of sheep and goats in three districts of Kaffa and Bench Maji Zones, Southwest Ethiopia
}

\author{
Tigist Kenea ${ }^{1}$, Jemere Bekele ${ }^{1}$ and Desie Sheferaw ${ }^{1 *}$ \\ ${ }^{1}$ Hawassa University School of Veterinary Medicine, P. O. Box 05, Hawassa, Ethiopia \\ *Corresponding author: Email: mereba480@gmail.com
}

\begin{abstract}
A cross-sectional study was conducted to estimate the prevalence and to identify the genera of gastrointestinal strongyles infecting sheep goats in Chena and Gimbo (Kaffa Zone) and Semen-Bench (Bench Maji zones) districts, Southwest Ethiopia. A total of 800 faecal samples were collected from sheep $(n=492)$ and goats $(\mathrm{n}=308)$, and then examined by floatation technique. Positive faecal samples were pooled and cultured and third stage larvae $\left(\mathrm{L}_{3}\right)$ were harvested and identified. From 800 examined faecal sample $433(54.1 \%)$ were positive for gastrointestinal parasites eggs. Among the risk factors considered in this study age, body condition and history of previous deworming showed significant $(\mathrm{P}<0.05)$ association with gastrointestinal parasites prevalence. Strongyle type eggs dominated the spectrum of infections, where by $73.1 \%$ sheep and $72.8 \%$ goats were positive for strongyles infection. From the pooled faecal sample culture seven nematode genera were identified in all the study districts (Chena, Gimbo and Semen-Bench) and both in sheep and goats. These genera include Bunostomum, Chabertia, Cooperia, Haemonchus, Oesophagostomum, Teladorsagia and Trichostrongylus. Among these Trichostrongylus, Bunostomum, Haemonchus and Cooperia were the dominant genera in all the three districts. This study indicated that gastrointestinal parasites were among the serious health problem both in sheep and goats in Kaffa and Bench Maji zones. Further study is required to identify the prevailing parasite species and assess the seasonal dynamics of the gastrointestinal parasites in the study areas and thereby to design appropriate control methods that enable to overcome the existing problem.
\end{abstract}

Keywords: Coproculture, Bench Maji, Ethiopia, Gastrointestinal parasites, Goats, Kaffa, Prevalence, Sheep

http://dx.doi.org/10.4314/evj.v19i2.6 


\section{Introduction}

Sheep and goats represent an important component of the farming system; because they require smaller investment, have shorter production cycles, faster growth rate and greater environmental adaptability than cattle (Lebbie, 2004; Anon, 2005). In the subsistence sector farmers and pastoralists depend on sheep and goats for much of their livelihood (Adane Hirpa and Girma Abebe, 2008).

Despite the large number of sheep (24.2 million) and goats (22.6 million) population in Ethiopia (CSA, 2012), the economic benefits remain marginal due to prevailing diseases, poor nutrition, poor production systems, reproductive inefficiency, management constraints and general lack of veterinary care. Diseases have a major impact on morbidity and mortality rates, with annual losses as high as $30-50 \%$ of the total value of livestock products of Ethiopia (Mukasa-Mugerwa et al., 2000). It is also estimated that approximately 5 to 7 million sheep and goats die from diseases and malnutrition each year in Ethiopia, which is accounting for a great annual financial loss (Anon, 1992; Tilahun Getachew, 1993).

Diseases caused by helminth parasites in livestock continue to be a major productivity constraint, especially in small ruminants in the tropics and subtropics (Perry et al., 2002). Sheep and goats under intensive and extensive production systems are extremely susceptible to the effects of wide range of helminth endoparasites (Abebe Wossene and Esayas Gelaye, 2001). Impacts of helminths could be reduced through implementation of appropriate control strategies that require knowledge of epidemiology and ecology of parasites under local conditions (Demelash Biffa et al., 2007; Boomker et al., 1994). Moreover, it is important to know which groups are present in a flock or herd in an area or region for effective control measures (Urquhart et al., 1996).

Therefore, the aim of this study is to estimate the prevalence and identify gastrointestinal nematode parasites in sheep and goats in Kaffa and Bench Maji Zones. 


\section{Materials and Methods}

\section{Study area and animals}

This study was carried out from November 2010 to April 2011 in Chena and Gimbo (Kaffa Zone), and Semen-Bench (Bench-Maji Zone) districts, Southwestern Ethiopia. The altitude of Chena, Gimbo and Semen-Bench districts was range from 500 to 2500,1400 to 2400 , and 1200 to 2200 meters above sea level, respectively. The area has a mean annual rainfall of 1284 to $1780 \mathrm{~mm}$, 900 to $1150 \mathrm{~mm}$ and 1500 to $2000 \mathrm{~mm}$, and the mean annual temperature is 11 $28^{\circ} \mathrm{C}, 14-28^{\circ} \mathrm{C}$ and $15-28^{\circ} \mathrm{C}$, respectively. The study areas are characterized by mixed crop-livestock production system.

The study sheep and goats were selected by systematic random sampling method from local indigenous breeds that were kept by traditional extensive management system and owned by smallholder farmers. The study animals were managed by communal free range grazing systems. A total of 800 animals (492 sheep and 308 goats) were examined over the study period. Age, sex, body condition and deworming history of the study animals were recorded during faecal sample collection. The study animals were categorized into two age groups: young ( $<1$ year) and adult $(\geq 1$ year).

\section{Sampling method and sample size}

A cross-sectional study method was employed to estimate the prevalence gastrointestinal nematodes and to identify the nematode genera prevailing in the areas. The sample size for the study was determined by considering $25 \%$ expected prevalence and based on the formula given by Thrusfield (2005). The study considered $95 \%$ level of precision.

\section{Study methodology}

Faecal samples were collected directly from the rectum of each studied animal. Then the samples were packed and labelled with all required information and transported to Mizan Regional Veterinary laboratory using ice box. The samples were kept at $4^{\circ} \mathrm{C}$ and processed within twenty four hours of collection. The faecal samples were examined qualitatively for the presence of strongyle eggs and quantitatively to assess the number of strongyle eggs per grams of faeces following the procedure described by Hansen and Perry (1994). 
Coproculture: From about $10 \%$ of positive faecal samples for strongyle eggs from animals of the same species and districts were pooled and cultured for larval identification. About $3 \mathrm{gms}$ of faeces from each positive animal were pooled and incubated at $27^{\circ} \mathrm{C}$ for 7 to 10 days. Then third stage larvae $\left(\mathrm{L}_{3}\right)$ recovered using modified Baermann technique was identified using the standard key for morphological feature (MAFF, 1979; van Wyk et al., 2004).

\section{Data analysis}

All collected data were entered into Microsoft Excel spread sheet, and then summarized by using descriptive statistics like mean and percentage. Pearson's chi-square test was employed to test the effect of risk factors on the prevalence of gastrointestinal nematodes.

\section{Results}

\section{Coproscopic results}

From a total of 800 examined animals 433 (54.1\%) were harboured gastrointestinal nematodes. The prevalence of gastrointestinal parasites in sheep $(n=492)$ and goats $(n=308)$ were $55.1 \%$ and $52.6 \%$, respectively (Table 1).

Table 1 Frequency of faecal nematode egg findings relative to the risk factors

\begin{tabular}{|c|c|c|c|c|c|c|}
\hline \multicolumn{2}{|c|}{ Risk factors and levels } & \multicolumn{2}{|c|}{ No examined No positive (\%) } & \multirow{2}{*}{$\frac{95 \% \text { CI }}{44.0-58.0}$} & \multirow{2}{*}{$\frac{\mathrm{x}^{2}}{1.49}$} & \multirow{2}{*}{$\begin{array}{l}\text { P-value } \\
0.475\end{array}$} \\
\hline District & Chena & 200 & $102(51.0 \%)$ & & & \\
\hline & Gimbo & 301 & $162(53.8 \%)$ & $48.2-59.5$ & & \\
\hline & S/ Bench & 299 & $169(56.5 \%)$ & $50.9-62.2$ & & \\
\hline \multirow[t]{2}{*}{ Species } & Sheep & 492 & $271(55.1 \%)$ & $50.7-59.5$ & 0.47 & 0.493 \\
\hline & Goats & 308 & $162(52.6 \%)$ & $47.0-58.2$ & & \\
\hline \multirow[t]{2}{*}{ Sex } & Male & 283 & $143(50.5 \%)$ & $44.7-56.4$ & 2.28 & 0.131 \\
\hline & Female & 517 & $290(56.1 \%)$ & $51.8-60.4$ & & \\
\hline \multirow[t]{2}{*}{ Age } & Young & 240 & $95(39.6 \%)$ & $33.4-45.8$ & 29.2 & 0.000 \\
\hline & Adult & 560 & $338(60.4 \%)$ & $56.3-64.4$ & & \\
\hline \multirow[t]{3}{*}{ Body condition } & Good & 497 & $200(40.2 \%)$ & $35.9-44.6$ & 114.42 & 0.000 \\
\hline & Medium & 129 & $84(65.1 \%)$ & $56.8-73.5$ & & \\
\hline & Poor & 174 & $149(85.6 \%)$ & $80.4-90.9$ & & \\
\hline \multirow[t]{2}{*}{ Deworming } & Yes & 54 & $20(37.0 \%)$ & $23.7-50.3$ & 6.81 & $0 . .009$ \\
\hline & No & 746 & $413(55.4 \%)$ & $51.8-58.9$ & & \\
\hline Total & & 800 & $433(54.1 \%)$ & $50.7-57.6$ & & \\
\hline
\end{tabular}


In the coproscopic examination using floatation techniques an overall $73.0 \%$ Strongyles type, $4.8 \%$ Strongyloides, $3.7 \%$ Trichuris, and $18.5 \%$ mixed (i.e. Strongyles, Strongyloides and Trichuris) types of eggs detected. The types of eggs observed for each of the study districts indicated in Table 2.

Table 2. The analysis for the egg types and their frequency in the study districts

\begin{tabular}{|c|c|c|c|c|c|}
\hline District & Egg types & Frequency (\%) & $95 \% \mathrm{CI}$ & $x^{2}$ & P-Value \\
\hline \multirow[t]{4}{*}{ Chena $(n=200)$} & Strongyle type & $80(74.4 \%)$ & $70.3-86.5$ & 120.00 & 0.000 \\
\hline & Strongyloides & $7(6.9 \%)$ & $1.9-11.9$ & & \\
\hline & Trichuris & $5(4.9 \%)$ & $0.6-9.2$ & & \\
\hline & Mixed infections & $10(9.8 \%)$ & $3.9-15.7$ & & \\
\hline \multirow[t]{4}{*}{ Gimbo $(n=301)$} & Strongyle type & $112(69.1 \%)$ & $62.0-76.3$ & 153.04 & 0.000 \\
\hline & Strongyloides & $6(3.7 \%)$ & $0.8-6.6$ & & \\
\hline & Trichuris & $9(5.6 \%)$ & $2.0-9.1$ & & \\
\hline & Mixed infection & $35(21.6 \%)$ & $15.2-28.0$ & & \\
\hline \multirow[t]{4}{*}{ Semen Bench $(n=299)$} & Strongyle type & $124(73.4 \%)$ & $66.6-80.1$ & 162.97 & 0.000 \\
\hline & Strongyloides & $8(4.7 \%)$ & $1.5-8.0$ & & \\
\hline & Trichuris & $2(2.1 \%)$ & $-0.5-2.8$ & & \\
\hline & Mixed infection & $35(20.7 \%)$ & $14.5-26.9$ & & \\
\hline
\end{tabular}

The coproscopic examination revealed that from sheep and goats positive for gastrointestinal nematodes $73.1 \%$ and $72.8 \%$ were found to harbour strongyle type eggs, respectively (Table 3 ).

Table 3. Types of egg and their frequency in sheep and goats.

\begin{tabular}{lllll}
\hline Species of host & Egg types & Frequency & Percentage & $\mathbf{9 5 \%}$ CI \\
\hline Sheep $(\mathrm{n}=492)$ & Strongyle type & 198 & 73.1 & $67.8-78.4$ \\
& Strongyloides & 13 & 4.8 & $2.2-7.4$ \\
& Trichuris & 12 & 4.8 & $2.0-6.9$ \\
& Mixed infections & 48 & 17.7 & $13.1-22.3$ \\
Goats $(\mathrm{n}=308)$ & Strongyle type & 118 & 72.8 & $65.9-79.8$ \\
& Strongyloides & 8 & 4.9 & $1.6-8.3$ \\
& Trichuris & 4 & 2.5 & $0.1-4.9$ \\
& Mixed infection & 32 & 19.8 & $13.6-26.0$ \\
\hline
\end{tabular}




\section{Coproculture results}

From pooled faecal culture 80, 112 and 124 larvae $\left(\mathrm{L}_{3}\right)$ harvested from animals examined in Chena, Gimbo and Semen-Bench districts, respectively. Examination of harvested $\mathrm{L}_{3}$ revealed a total of seven genera gastrointestinal nematode, namely: Bunostomum, Chabertia, Cooperia, Haemonchus, Oesophagostomum, Teladorsagia and Trichostrongylus. The observed proportion of $\mathrm{L}_{3}$ in each district is shown in Table 4 .

Table 4 Gastrointestinal nematodes genera identified in the three study districts

\begin{tabular}{|c|c|c|c|c|}
\hline District & General & Frequency & Percent (\%) & $95 \% \mathrm{CI}$ \\
\hline \multirow[t]{7}{*}{ Chena $(n=200)$} & Bunostomum & 18 & 25.50 & $13.14-31.85$ \\
\hline & Chabertia & 2 & 2.50 & $-0.99-5.99$ \\
\hline & Cooperia & 11 & 13.75 & $6.04-21.46$ \\
\hline & Haemonchus & 14 & 17.50 & $8.99-26.00$ \\
\hline & Oesophagostomum & 2 & 2.50 & $-0.99-5.99$ \\
\hline & Teladorsagia & 16 & 20.00 & $11.04-28.95$ \\
\hline & Trichostrongylus & 17 & 21.25 & $12.09-30.41$ \\
\hline \multirow[t]{7}{*}{ Gimbo $(n=301)$} & Bunostomum & 26 & 23.21 & $15.27-31.15$ \\
\hline & Chabertia & 1 & 0.89 & $-0.87-2.66$ \\
\hline & Cooperia & 29 & 25.89 & $17.65-34.13$ \\
\hline & Haemonchus & 17 & 15.18 & $8.43-21.92$ \\
\hline & Oesophagostomum & 1 & 0.89 & $-0.87-2.66$ \\
\hline & Teladorsagia & 3 & 2.68 & $-0.36-5.71$ \\
\hline & Trichostrongylus & 35 & 31.25 & 22.53-39.97 \\
\hline \multirow{7}{*}{$\begin{array}{l}\text { Semen Bench } \\
(n=299)\end{array}$} & Bunostomum & 22 & 17.74 & $10.92-24.56$ \\
\hline & Chabertia & 6 & 4.84 & $1.01-8.67$ \\
\hline & Cooperia & 16 & 12.90 & $6.92-18.89$ \\
\hline & Haemonchus & 19 & 15.32 & $8.89-21.75$ \\
\hline & Oesophagostomum & 12 & 9.68 & $4.40-14.95$ \\
\hline & Teladorsagia & 9 & 7.26 & $2.63-11.89$ \\
\hline & Trichostrongylus & 40 & 32.26 & $23.91-40.60$ \\
\hline
\end{tabular}

From pooled faecal culture of sheep and goats a total of 198 and 118 L3 harvested, respectively. Examination of recovered L3 revealed seven genera of gastrointestinal nematodes both in sheep and goats (Table 5). 
Table 5 Gastrointestinal nematodes genera identified in sheep and goats

\begin{tabular}{lllll|}
\hline District & Parasite genera & Frequency & Percent (\%) & $\mathbf{9 5 \%}$ CI \\
\hline Sheep $(\mathrm{n}=492)$ & Bunostomum & 37 & 18.69 & $13.21-24.16$ \\
& Chabertia & 7 & 3.54 & $0.94-6.13$ \\
& Cooperia & 35 & 17.68 & $12.32-23.03$ \\
& Haemonchus & 37 & 18.69 & $13.21-24.16$ \\
& Oesophagostomum & 9 & 4.55 & $1.62-7.47$ \\
& Teladorsagia & 13 & 6.57 & $3.09-10.05$ \\
Goats $(\mathrm{n}=308)$ & 60 & 30.30 & $23.84-36.76$ \\
& Trichostrongylus & 29 & 24.88 & $16.69-32.46$ \\
& Bunostomum & 2 & 1.69 & $-0.67-4.06$ \\
& Chabertia & 21 & 17.80 & $10.79-24.79$ \\
& Cooperia & 13 & 11.02 & $5.28-16.75$ \\
& Haemonchus & 6 & 5.08 & $1.06-9.11$ \\
& Oesophagostomum & $\mathbf{6}$ & 12.71 & $6.61-18.81$ \\
& Teladorsagia & 15 & 27.12 & $18.98-35.26$ \\
\hline
\end{tabular}

\section{Discussion}

This study revealed an overall coproscopic prevalence of $54.1 \%$ gastrointestinal parasites infection in sheep and goats (i.e. $55.1 \%$ in sheep and $52.6 \%$ in goats). This finding is comparable with some reports from Ethiopia (Fikru Regassa et al., 2006; Rahmeto Abebe et al., 2010; Jalelie Datiko et al., 2013; Diriba Lemma and Birhanu Abera, 2013). Similar to the report of Rahmeto Abebe et al (2010) the prevalence of strongyle infection in sheep and goats showed no significant $(\mathrm{P}>0.05)$ variation. This might be due to similarities in agroecology and in management of both sheep and goats, kept by traditional extensive management system (Zalac, 2006). The study area characterized by communal grazing area, and hence, both sheep and goats have equal chance to acquire the infective larvae of strongyles.

The prevalence of strongyle infection was significantly higher $(\mathrm{P}<0.01)$ in adult, poor body condition and not dewormed animals than in young, medium and/or good body condition and dewormed animals. The lower prevalence of strongyle infection in younger animals could be most likely due to the tradition of keeping young animals homestead than letting them to travel distance in search of grass, which could be due to fears for wild predators and young animals are unable to walk long distances in search of grass. 
Animals with poor body condition tend to harbour a significantly higher strongyle infection rate than others, which is in agreement with the previous works (Fikru Regassa et al., 2006; Rahmeto Abebe et al., 2010). In fact the poor body condition could be due to the strongyle itself or other diseases or nutritional problems. Whatever the cause, there is compromised immune response to infection in poor body condition animals (Skyes, 2010).

Based on the egg types, the proportion of strongyle is significantly higher ( $\mathrm{P}$ $<0.05$ ) both in sheep and goats. This observation is in agreement with Fikru Regassa et al (2006) and Diriba Lemma and Birhanu Abera (2013).

From coproculture and third stage larvae identification seven genera of nematodes were identified in all the study districts and both animal species, namely Trichostrongylus, Bunostomum, Haemonchus, Cooperia, Teladorsagia, Oesophagostomum and Chabertia. Among these Trichostrongylus, Bunostomum, Haemonchus and Cooperia were the dominant genera in all the three districts. Reports from various parts of Ethiopia indicated that the genera Trichostrongylus, Haemonchus and Bunostomum are widely spread (Abebe Wossene and Esayas Gelaye, 2001; Tembely et al., 1997; Amenu Asha and Abebe Wossene, 2007; Bersissa Kumsa and Ajebu Nurfeta, 2008; Rahmeto Abebe et al., 2010; Molalegne Bitew et al., 2011; Tesfaheywet Zeryehun, 2012; Gonfa Shankute et al., 2013).

\section{Conclusion}

Further investigation involving wider areas, larger sample size and seasonal dynamics of gastrointestinal nematodes should be required. But based on the result of this study appropriate strategic control should be designed to overcome the problem.

\section{References}

Abebe, R., Gebreyohannes, M., Mekuria, S., Abunna, F. and Regassa A., 2010. Gastrointestinal nematode infections in small ruminants under the traditional husbandry system during the dry season in southern Ethiopia. Tropical Animal Health and Production, 42, 1111-1117.

Abebe, W. and Esayas, G., 2001. Survey of ovine and caprine gastrointestinal helminthosis in eastern parts of Ethiopia during the dry season of the year. Revue de medicine veterinaries, $152,379-384$. 
Anon, 2005. Agricultural Sample Survey, 2004/2005 (1997 E.C.), Volume II. Report on Livestock and Livestock Characteristics (Private Peasant Holdings). Statistical Bulletin, 331, Central Statistical Authority, Addis Ababa, Ethiopia.

Anon, 1992. Ethiopia: Livestock Sector Development Project. Food and Agriculture Organization of the United Nations, Report №. 107/92.FAO, Rome, Italy.

Asha, A. and Wossene, A., 2007. Gastrointestinal tract nematodosis of small ruminants in three different agro-ecological zones in southern Ethiopia. Ethiopian Vet. Journal, 11 (1), 83-94.

Bersissa, K. and Ajebu, N., 2008. Comparative efficacy of albendazole, tetramisole and ivermectin against gastrointestinal nematodes in naturally infected sheep in Hawassa, southern Ethiopia. Revue éd. Vét., 159 (12), 593-598.

Biffa, D., Jobre. Y. and Chakka, H., 2007. Ovine helminthosis, a major health constraint to productivity of sheep in Ethiopia. Animal Health Research Reviews, 7 (1/2), 107118.

Bitew, M., Amde, Y. and Belachew, K., 2011. Abomasal and intestinal nematodes of small ruminants slaughtered in different restaurants in Hawassa. Veterinary Research, 4 (2), 39-44.

Boomker, J., Horak, I.G. and Ramsay, K. A., 1994. Helminth and arthropod parasite of indigenous goats in the northern Transvaal. Onderstepoort Journal of veterinary research, 61, 13-20.

CSA, 2012. Report on livestock and livestock characteristics, Federal democratic republic of Ethiopia Central Statistical Agency Agricultural sample survey 2011/12 (2004 E.C.), Volume II, Statistical Bulletin 532, Addis Ababa, Ethiopia.

Datiko, J., Terefe, G. and Bekele, J., 2013. Anthelmintic utilization practices and prevalence of gastrointestinal helminth infections in sheep kept in the urban and peri-urban areas of Bishoftu Town. Trop. Anim. Health. Prod., 45 (2), 633-639.

Hansen, J., and Perry, B., 1994. The Epidemiology, diagnosis and control of helminth parasite of ruminants, A hand book, $2^{\text {nd }}$ edition, ILRAD, Nairobi, Kenya.

Hirpa, A. and Abebe, G., 2008. Economics significance of sheep and goats. In: Yami A and Merkel RC (Edition), Sheep and goat production handbook for Ethiopia, ESGPIP, Ethiopia, pp. 1-4.

Lebbie, S.H.B., 2004. Goats under household conditions. Small ruminant research, 51, 131-136.

Lemma, D. and Abera, B., 2013. Prevalence of ovine gastrointestinal nematodes in and around Asella, South Eastern Ethiopia. Journal of Veterinary Medicine and Animal Health, 5 (8), 222-228. 
MAFF, 1979. Manual of Veterinary Parasitological laboratory techniques, Technical Bulletin No.18, London.

Mukasa-Mugerwa, E., Lahlou-Kassi, A., Anindo, D., Rege, J.E.O., Tembely, S., Tibbo, M. and Baker, R.L., 2000. Between and within breed variation in lamb survival and the risk factors associated with major causes of mortality in indigenous Horro and Menz sheep in Ethiopia. Small Ruminant Research, 37, 1-12.

Perry, B.D., Randolph, T.F., McDermott, J.J., Sones, K.R. and Thornton, P.K., 20002. Investing in animal health research to alleviate poverty, ILRI, Nairobi, Kenya, pp. 148.

Regassa, F., Sori, T., Dhuguma, R. and Kiros, Y., 2006. Epidemiology of Gastrointestinal Parasites of Ruminants in Western Oromia, Ethiopia. Intern. J. Appl. Res. Vet. Med., 4 (1), 51-57.

Shankute, G., Bogale, B. and Melaku, A., 2013. An abattoir survey on gastrointestinal nematodes in sheep and goats in Hemex Export abattoir, Debre-Zeit, Central Ethiopia. Journal of Advanced Veterinary Research, 3, 60-63.

Sykes, A.R., 2010. Host immune responses to nematodes: benefit or cost? Implications for future development of sustainable methods of control. Revista Brasileira de Zootecnia, 39, 376-382.

Tembely, S., Lahlou-Kassi, A., Rege, J.E.O, Sovani, S., Diedhiou, M.L. and Baker, R.L., 1997. The epidemiology of nematode infections in sheep in cool tropical environment. Veterinary Parasitology, 70, 129-141.

Thrusfield, M., 2005. Veterinary epidemiology,. $3^{\text {rd }}$ edition, Blackwell science Ltd., Blackwell Publishing company, Oxford, UK, pp. 231-34.

Tilahun, G., 1993. A survey of fascioliasis in cattle, sheep and goats slaughtered at Addis Ababa abattoir. In: Arosenius, C., Jacobsen, L., Lindberg, R. and Nilsson, P.O. (Eds.), Animal Diseases of the Gastro-intestinal Tract and Liver: An African Perspective. Proceedings of a seminar held at ILCA (International Livestock Centre for Africa), Addis Ababa, Ethiopia, pp. 125-133.

Urquhart, G.M., Armour, J., Duncan, J.L., Dunn, A.M. and Jennings, F.W., 1996. Veterinary Parasitology, Second edition, Black well science, United Kingdom.

van Wyk, J.A., Cabaret, J. and Michael, L.M., 2004. Morphological identification of nematode larvae of small ruminants and cattle simplified. Veterinary Parasitology, 119, 277-306.

Zalac, A.M., 2006. Gastrointestinal nematodes of small ruminants: life cycle, Anthelminyics, and diagnosis. Vet. Clin. North Am. Food Anim. Pract., 22 (3), 529-541.

Zeryehun, T., 2012. Helminthosis of sheep and goats in and around Haramaya, Southeastern Ethiopia. Journal of Veterinary Medicine and Animal Health, 4 (3), 48-55. 